This is the author's final version of the contribution published as:

Frye C.; Bo E.; Calamandrei G.; Calzà L.; Dessì-Fulgheri F.; Fernandez M.; Fusani L.; Kah O.; Kajta M.; Le Page Y.; Patisaul H.B.; Venerosi A; Wojtowicz A.K.; Panzica G.C.. Endocrine disrupters: a review of some sources, effects, and mechanisms of actions on behavior and neuroendocrine systems. JOURNAL OF NEUROENDOCRINOLOGY. 24 (1) pp: 144-159. DOI: $10.1111 / \mathrm{j} .1365-2826.2011 .02229 . \mathrm{x}$

The publisher's version is available at:

http://doi.wiley.com/10.1111/j.1365-2826.2011.02229.x

When citing, please refer to the published version.

Link to this full text:

http://hdl.handle.net/2318/88647 
Journal of Neuroendocrinology

\section{Milestones on steroids and the nervous system: Ten years of basic and translational research}

\begin{tabular}{|r|l|}
\hline Journal: & Journal of Neuroendocrinology \\
\hline Manuscript ID: & JNE-11-0283-RA.R1 \\
\hline Manuscript Type: & Review Article \\
\hline Date Submitted by the Author: & n/a \\
\hline Complete List of Authors: & $\begin{array}{l}\text { Panzica, GianCarlo; University of Torino, Anatomia, Farmacologia e } \\
\text { Medicina Legale } \\
\text { Balthazart, Jacques; University of Liege, Center for Cellular and Molecular } \\
\text { Neurobiology } \\
\text { Frye, Cheryl; SUNY Albany, Psychology } \\
\text { Garcia-Segura, Luis; Instituto Cajal, CSIC, } \\
\text { Herbison, Allan; University of Otago, Department of Physiology } \\
\text { Mensah-NyagaN, Guy; Université de Strasbourg, Equipe Stéroïdes, } \\
\text { Neuromodulateurs et Neuropathologies } \\
\text { McCarthy, Margaret; Univ. Maryland Baltimore, Physiology } \\
\text { Melcangi, Roberto; University of Milan, Dept. Endocrinology }\end{array}$ \\
\hline Keywords: & $\begin{array}{l}\text { neurosteroids, behavior, sex differences, neuroprotection, GnRH, } \\
\text { Kisspeptin }\end{array}$ \\
\hline
\end{tabular}




\section{Milestones on steroids and the nervous system: Ten years of basic and translational research.}

Panzica G.C. ${ }^{1,2}$, Balthazart J. ${ }^{3}$, Frye C.M. ${ }^{4}$, Garcia-Segura L.M. ${ }^{5}$, Herbison A.E. ${ }^{6}$, Mensah-Nyagan A.G. ${ }^{7}$, McCarthy M.M. ${ }^{8}$, Melcangi R.C. ${ }^{9}$

${ }^{1}$ Laboratory of Neuroendocrinology, Department of Anatomy, Pharmacology and Forensic Medicine, Neuroscience Institute of Turin (NIT), University of Torino, Torino, Italy

${ }^{2}$ Neuroscience Institute Cavalieri-Ottolenghi (NICO), Orbassano (Torino), Italy

${ }^{3}$ University of Liège, GIGA Neuroscience, Research Group in Behavioral Neuroendocrinology, Liège, Belgium

${ }^{4}$ Department Psychology, University at Albany, Albany, NY (USA)

${ }^{5}$ Instituto Cajal, CSIC, Madrid, Spain

${ }^{6}$ Centre for Neuroendocrinology, Department of Physiology, University of Otago, Dunedin, New Zealand

${ }^{7}$ Equipe Stéroïdes, Neuromodulateurs et Neuropathologies, EA-4438 Université de Strasbourg, Strasbourg, France.

${ }^{8}$ Departments of Physiology, School of Medicine, University of Maryland, Baltimore, Maryland

${ }^{9}$ Dept. of Endocrinology, Pathophysiology and Applied Biology - Center of Excellence on Neurodegenerative Diseases, University of Milano, Milano, Italy

Corresponding author

GianCarlo Panzica, PhD

Dept.Anatomy, Pharmacology and Forensic Medicine, Neuroscience Institute of Torino (NIT), University of Torino.

Neuroscience Institute Cavalieri-Ottolenghi (NICO)

Regione Gonzole, 10 - 10043 Orbassano (TO), Italy

Phone +39011 6706607

Fax +390112366607

e-mail: giancarlo.panzica@unito.it 
Ten years of the Torino Steroids' Meeting

\begin{abstract}
During the last ten years, the conference on "Steroids and Nervous System" held in Torino (Italy) was an important international point of discussion for scientists involved in this exciting and expanding research field. The present review aimed to recapitulate the main topics that were presented through the various editions of the meeting. Two broad areas were explored: the impact of gonadal hormones on brain circuits and behaviour, and the mechanism of action of neuroactive steroids. Relationships among steroids, brain and behaviour, the sexual differentiation of the brain and the impact of gonadal hormones, the interactions of exogenous steroidal molecules (endocrine disrupters) with neural circuits and behaviour, and how gonadal steroids modulate the behaviour of $\mathrm{GnRH}$ neurones were the topics of several lectures and symposia during this series of meetings. At the same time, many contributions were dedicated to the biosynthetic pathways, the physiopathological relevance of neurosteroids, and the demonstration of the cellular localization of different enzymes involved in neurosteroidogenesis, the mechanisms by which steroids may exert some of their effects, both classical and non-classical action of different steroids, the role of neuroactive steroids on neurodegeneration, neuroprotection and the response of the neural tissue to injury. In these 10 years, this field has significantly advanced and neuroactive steroids have emerged as new potential therapeutic tools to counteract neurodegenerative events.
\end{abstract}

Keywords: neurosteroids, brain, peripheral nerve, sex difference, neuroprotection, GnRH, kisspeptin, behaviour 
The conference on "Steroids and the Nervous System" emerged as a "spin-off" from a conference specifically dedicated to the neuroendocrine controls of behaviour. The International Conference on Hormones, Brain and Behaviour" (ICHBB) met several times in various locations in Europe during the eighties and nineties (Bielfeld, Germany, 1982; Liege, BE, 1984 and 1989; Tours, FR, 1993; Torino, IT, 1996 and finally Madrid, SP, 2000). After ICHBB was merged with the activities of the Society for Behavioral Neuroendocrinology (SBN) that had been created in 1997, Gian Carlo Panzica (University of Torino) and Roberto C. Melcangi (University of Milan) decided that it would be important to keep a conference regularly meeting in Europe and dealing with steroid action in the brain. A cycle of conferences using essentially the same format as ICHBB was therefore initiated that has now met every two years for the past 10 years (2001, 2003, 2005, 2007, 2009 and 2011, fig.1) (see http://www.dafml.unito.it/anatomy/panzica/neurosteroids/ABSTRACTBOOKS.htm).

The scope of the conference has been expanded from the behavioural effects of steroids in the brain to cover all forms of steroid actions, the controls of steroid synthesis in the brain and in the peripheral nervous system, as well as the emerging translational models.

\section{Steroids and behaviour at the Torino meeting}

Glancing through the programs of these 6 conferences summarizing 10 years of research on steroids, one can identify a large number of symposia that were essentially or even exclusively dedicated to "Steroids, Brain and Behaviour". The topics that were covered in these symposia concern many aspects of the active research that took place in this field during the last decade. To list just a few, we had over the years the chance of attending symposia dedicated to behavioural effects of steroids as well as to the action of environmental oestrogens on behaviourally relevant neural circuits (2003) (1), on brain sexual differentiation (2005), on the importance of co-regulatory factors for steroid receptor action in the brain (2009) and on experimental murine models (2011).

Several round tables were also organised within the meeting during which we discussed the action of endocrine disrupter action on behaviour and neuroendocrine system $(2005,2011)$, and that of steroid hormones on sexually dimorphic brain circuits (2007). It must be mentioned that, as impressive as they are, all these 
symposia only provide a partial view of the time and talks that were devoted to behaviour during the meeting on Steroids and Nervous System. There were indeed many individual presentations on behaviour embedded in other symposia and these are far too numerous to be cited here. Starting from 2003, each meeting had additionally a few (usually 3) key-note speakers and many of the key-note lectures concerned, at least in part, the mechanisms of behaviour. During the 2003 meeting the attention was focused on the oestradiol modulation of astrocytes and the establishment of sex differences in the brain (2) and on the role of sex chromosomes in sexual differentiation of the brain (3). In the 2005 meeting, the speakers presented data on the rapid changes in the production and behavioural action of oestrogens (4) and on genetic models for the study of gonadal steroid dependent behaviours (5). In 2007 the attention was on the stress system in the human brain in depression and neurodegeneration (6). In 2009 meeting one of the key-note lectures was on the intracellular signal transduction cascades mediating behavioural effects of ovarian steroids (7). Finally, in 2011 we had lectures on comparative and functional implications of neurosteroidogenesis (8) and on oestrogen-induced plasticity and cognitive function (9). And that is without counting the large number of posters that were presented on themes related to the main talks and symposia and that were very often using behaviour as their dependent (or sometimes independent) variable.

Finally, in association with the "Torino meeting", as it has often been colloquially named, a satellite one-day symposium entirely dedicated to the endocrine control of behaviour was organised in 2009. It was named $7^{\text {th }}$ ICHBB to celebrate the synchronised $60^{\text {th }}$ birthday of the organisers of both the Torino Steroid meeting (Gian Carlo Panzica) and of the former ICHBB (Jacques Balthazart). At a more scientific level, this $7^{\text {th }}$ ICHBB also coincided with the $50^{\text {th }}$ anniversary of the publication of the seminal paper of Phoenix and collaborators (10) universally recognised as the founding paper for the research analyzing the endocrine controls of sexual differentiation of brain and behaviour.

With the exception of this satellite symposium, many of the talks and symposia mentioned above were not exclusively dedicated to the analysis of behaviour. They also concerned other topics such as the non-classical effects of steroids or the effects of steroids on the sexual differentiation of the brain. But in each case, they were behaviourally relevant in that either the changes in brain structure or function could contribute to explain behaviour or changes in behaviour were the driving force 
leading to changes in the brain or in steroid synthesis.

\section{Ten years of progress in understanding sexual differentiation of the brain. What we knew at the beginning of the $21^{\text {st }}$ Century.}

It has been a busy ten years for the field of behavioural neuroendocrinology and the topic of sexual differentiation of the brain in particular. As we entered this century we had a strong foundation of immutable facts about the physiological process of sexual differentiation of brain and behaviour; 1) hormones of gonadal origin are the preeminent determinant of sex differences in brain and behaviour, 2) sex differences in levels of gonadal hormones during a sensitive period of brain development will organise the brain into a sex-specific phenotype and 3) sex differences in levels of gonadal hormones in adulthood will activate the previously determined sex-specific brain phenotype in order to drive sex-specific physiology and behaviour. These are the basic facts but many aspects of the details vary by species, by physiological or behavioural endpoint and by brain region. In many cases the basic facts do not even apply. Nonetheless, the sturdy framework of the Organizational/Activational Hypothesis (10), which essentially codifies the three basic facts just enumerated, continues to provide a valuable backdrop against which to address all questions of the origins and significance of sex differences in the brain. Nothing is more valuable to scientific investigation than a dogma to be over thrown.

\section{Dogma's overthrown.}

There have been several major challenges to the dogma in the past 10 years, some have indeed created a paradigm shift in our thinking while others have offered refinements and qualifiers, notable exceptions or a more nuanced understanding. The biggest impact was the development of a mouse model that allowed for distinguishing between genetic, or chromosomal sex, and gonadal sex. The generation of animals with an XX genotype and a male phenotype (i.e. testes) or an XY genotype and a female phenotype (i.e. ovaries), allowed Art Arnold and his collaborators to ask for the first time whether all sex differences in the brain are determined by hormones $(3$, 11). The answer is, not surprisingly, mixed. Based on the current data to-date, it would appear that the sexual differentiation of endpoints that are directly relevant to reproduction, i.e. sexual behaviour and control of gonadotropin secretion and the brain areas that mediate them, are indeed subject to the classic hormonally mediated sexual differentiation of the brain. However, sex differences in endpoints that involve 
cognition, emotion or sensory integration are often influenced by chromosomal sex, sometimes markedly so. The next ten years will no doubt further advance our knowledge on this front by using genetic models such as the steroidogenic factor 1 (Nr5a1) knock-out mice which lack gonads (12) and by identifying specific X or Y genes and the associated mechanism of action.

Discoveries more in the realm of refinements to the theory are found in the characterization of genetically modified mice in which aromatase, androgen receptor or either isoform of the oestrogen receptor (ER) is either globally or locally and conditionally ablated. We have learned that in the rodent the long held dominance of oestradiol as the masculinizing hormone needs to make some room for androgens as important contributors to the natural process (13-18), and that ER $\alpha$ versus ER $\beta$ expression in a particular brain region mediates different responses (19-21). Our views of oestrogens effects have been further refined as well. First, steroid receptors are no longer mere transcription factors that mediate gene expression in a slow stately and direct manner, but instead can act rapidly at the membrane and integrate signal transduction pathways across a wide range of avenues $(22,23)$. Second, we now know oestradiol is more than just a gonadal hormone, it is also synthesised locally and rapidly and on demand, so much so that its resemblance to a neurotransmitters has been noted (24). Rapid membrane-mediated effects of oestradiol have been confirmed to contribute to the process of sexual differentiation of brain and behaviour (25), but what role local steroidogenesis plays in the process is not yet clear.

\section{Advances made.}

The distinction between the active processes of masculinisation and defeminisation of the male brain has long puzzled behavioural neuroendocrinologists and the last decade has seen several advances along this front. Characterization of null mutant mice suggests that the beta isoform of the oestrogen receptor is central to defeminisation (26), but how this is so is not clear. During the 2011 meeting a symposium was dedicated to the role of ER $\beta$ in adult brain function (27). The surprising discovery that the final common pathway mediating masculinisation of sex behaviour in the rat is the prostaglandin PGE2, also included the observation that prostaglandin mediated masculinisation does not influence defeminisation, and provided a unique tool for parsing out these separate processes in the same animal $(28,29)$. Lastly, feminisation of brain development has always been the poor cousin 
to the more tractable process of masculinisation but recent findings $(30,31)$ has revealed a heretofore unappreciated second sensitive period in which elevated oestradiol feminises the brain. This period is about a week to 10 days later than masculinisation in the rodent and elucidating the origins, sites of action and mechanisms of action of oestradiol during this later period will be an important topic in the coming years.

\section{Future directions}

At this writing we are at the beginning stages of several important new developments in the study of sex differences in the brain, some mechanistic and others theoretical. On the mechanistic front, it is apparent that the enduring organizational effects of steroids on the brain likely involve some sort of epigenetic changes to the genome. These include changes to the chromatin $(32,33)$ and the DNA $(34-36)$, but how these changes are integrated, maintained or perhaps modulated, remains to be determined. Epigenetic changes are certainly regionally specific, and may be an important component of the regional specificity of hormone action in general. This regional specificity compels us to reconsider the Organisational/Activational Hypothesis as many early hormonally mediated effects on the brain do not seem to follow the rules of this simple theory, suggesting new rules or guidelines are waiting for us to elucidate them. An important first step in that process comes from the novel view that we should also consider that the purpose of some sex differences in the brain is to make males and females more alike than different (37).

\section{Brain and behaviour, targets for the endocrine disrupters.}

The concept that exogenous substances may interfere with the normal development of brain and behaviour is not new, and it is at the basis of a large number of experimental studies. For instance, many studies on the sexual differentiation of rodent preoptic-hypothalamic circuits were conducted by using more powerful synthetic oestrogens like diethylstilbestrol [DES, (38)] or ethynylestradiol [ $\left.\mathrm{EE}_{2},(39)\right]$. However, during the years it appeared that these substances and many others that are able to bind oestrogen or androgen receptors are not limited to the laboratory use, but, due to their large-scale use in pharmaceutical or other industries, they are also widely present in the environment. In addition, some molecules of natural origin, like phytoestrogens produced by a large number of plants and normally present in the animal and human food, may also interact with gonadal hormone receptors. 
These substances were collectively named endocrine disrupters or endocrine disrupting chemicals (EDCs), a term that was coined early in 90'. In early papers (40), EDCs were defined as molecules that may disrupt the development of the endocrine system. In addition, the effects of EDCs' exposure during development are often permanent. A large consensus on this idea came from the Endocrine Society that released a scientific statement outlining mechanisms and effects of EDCs (41). Even if neuroendocrinology was specifically mentioned, for many years the study of EDCs involved almost exclusively the toxicological aspects, whereas the neuroendocrine and behavioural implications of precocious exposure to EDCs were less investigated.

Just from the first Torino's meeting in 2001 the issue of neuroendocrine and behavioural effects of EDCs emerged as one of the main topics of the conference. In fact, in that occasion were presented data on the effects of phytoestrogens contained in the food on the expression and regulation of cerebral androgen and progesterone metabolizing enzymes (42), as well as on anxiety behaviour and visual-spatial memory $(43,44)$.

During the $2^{\text {nd }}$ meeting in 2003, a satellite symposium was dedicated to the action of environmental oestrogens on behaviourally relevant neural circuits. This symposium was the follow up of a series of meetings centered on the actions of EDCs on behaviour and associated neural circuits, considered as more sensitive endpoints than other targets $(45,46)$.

The proceedings of this symposium (1) covered different experimental models including teleost fishes [somatostatin receptor (47)], birds [the vasotocin system (48, $49)$, the catecholaminergic system $(50)$, and the male copulatory behaviour $(48,51)$ of the Japanese quail], and rodents [catecholaminergic system (52), socio-sexual behaviours (53-55), oestrogen receptors $(56)$, and brain plasticity $(57,58)]$. These contributions provided important information on the action of single EDCs, as well as insights into the neural mechanisms by which these EDCs exert their effects.

During the $3^{\text {rd }}$ meeting, data on the rapid influence of oestrogens on the excitability of adult rat hippocampal neurones were presented (59-61). These findings have led researchers to postulate the existence of so-called membrane or non-genomic oestrogen effects. EDCs able to bind oestrogen receptors (xenoestrogens) also act rapidly in the adult brain. For example, the oestradiol-induced enhancement of the long-term potentiation in CA1 upon tetanic stimulation was considerably suppressed by the co-perfusion with bisphenol A (BPA), although the perfusion of BPA alone did 
not alter the LTP-induction (62). On the other hand, DES enhanced the LTP by an almost identical magnitude to that obtained by oestradiol. EDCs can reach the brain via the blood circulation and by crossing the blood-brain barriers.

A symposium on the cerebral effects of xenoestrogens was again organised during the $4^{\text {th }}$ meeting. This symposium included studies on the effects of BPA on the modulation of long-term depression and spinogenesis in the hippocampus (63), on the expression of oestrogen receptor (64), and on the development of the rodent (65) and avian brain (66).

During the $5^{\text {th }}$ meeting, endocrine disruptors were considered among the wide family of steroid receptors coactivators (67), in particular modulating the expression of sexually dimorphic social and emotional behaviours (68). Finally, during the last meeting, whose proceedings are collected in this special issue, a round table on endocrine disrupter action on behaviour and neuroendocrine system has been organised (69).

In summary, during these ten years we observed an increasing interest in the field of EDCs, mainly related to the potentially adverse effects on the sexual differentiation of brain and behaviour. Some important facts emerged in this field:

- sexual behaviour and neural circuits related to its control are more sensitive endpoints than others currently used in toxicological studies $(70,71)$;

- neuropeptides and enzymes are major targets for the action of EDCs in the vertebrate brain (72);

- among different peptidergic systems kisspeptin in rodents (73-77), vasotocin in birds $(48,78,79)$, as well as the enzyme aromatase in fishes $(80-82)$, or the enzyme NO-synthase in rodents $(83,84)$ appear the most sensitive to low levels of EDCs during early development;

- alterations of these circuits may induce profound effects on sexual behaviour (85), puberty (74), reproductive physiology (86), and feeding behaviour (87);

- neural circuits can be altered also at synaptic levels, for example in the hippocampus $(63,88-90)$ and have profound effects on learning and memory (91);

- the putative mechanisms of action needs to be more thoroughly explored (69), but in addition to the EDCs binding to steroid or thyroid hormone receptors, they include the aryl hydrocarbon receptor, its interactions with ER $\beta$, the activation of the P450 cytochromes, which are involved in the metabolism of most steroid 
hormones, the PPAR $\gamma$ and retinoid receptors particularly important in adipose tissue.

\section{Synthesis of neurosteroids}

In the research area on steroids and nervous system, the 3 last decades were significantly marked by a major finding that revealed that neurones and glial cells have the ability to synthesise bioactive steroids, also called neurosteroids (92). This important discovery stemmed from a series of pioneer works showing the persistence of substantial amounts of pregnenolone, dehydroepiandrosterone and their sulfated derivatives in the rodent brain after adrenalectomy and/or gonadectomy (93, 94). However, the consolidation of the concept of neurosteroids required several investigations performed in different animal species (92, 95-97).

Since its creation, the International Meeting Steroids and Nervous System has steadily contributed through various symposia and plenary lectures to the elucidation of the biosynthetic pathways and mechanisms of action of neurosteroids. For instance, the first meeting (2001) has been launched with a symposium that provided key data on neurosteroid biosynthesis in mammalian and non-mammalian vertebrates $(98,99)$. The second meeting allowed fruitful discussion from talks on neurosteroid metabolism in the human brain (100) or neurosteroid production in the retina (101). During the $3^{\text {rd }}$ meeting (2005), a satellite symposium made it possible to discuss the neuroprotective effects of steroids locally produced by the spinal cord and peripheral nervous system (102). In addition, a symposium of the main meeting discussed the role of steroidogenic acute regulatory protein and peripheral benzodiazepine receptors in neurosteroid biosynthesis $(103,104)$. Novel technological tools allowing highsensitive dosage of neurosteroids were presented in a satellite symposium of the $4^{\text {th }}$ meeting (105). To review and update the current knowledge on neurosteroid synthesis and functions, the opening lecture of the $6^{\text {th }}$ meeting was dedicated to a comparative and functional analysis of neurosteroidogenesis (8), and a satellite symposium was focused to neuroactive steroids in the human brain (106).

Taken together, all of the data provided by renowned experts in symposia and proceedings of the International Meeting Steroids and Nervous have significantly contributed to clarify the biosynthetic pathways and physiopathological relevance of neurosteroids. Nowadays, a consensual definition of neurosteroids considers these 
molecules as endogenous steroidal compounds synthesised in neurones or glial cells of the CNS and PNS. To be qualified as a neurosteroid, the candidate steroidal molecule must persist in substantial amounts in the nervous system after removal of the peripheral or traditional steroidogenic glands such as the adrenals and gonads. The demonstration of neurosteroid biosynthesis requires the localization in nerve cells of the translocator protein $18 \mathrm{kDa}$, the steroidogenic acute regulatory protein and active

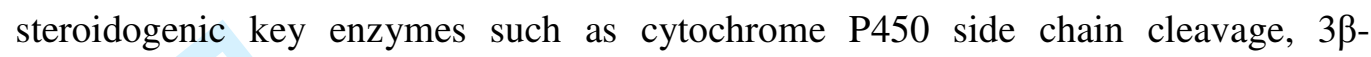

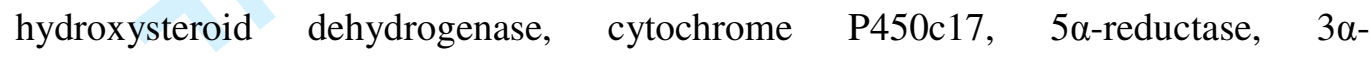
hydroxysteroid oxido-reductase, 17 $\beta$-hydroxysteroid dehydrogenase and aromatase (92, 95-97, 107, 108).

Finally, it should also be noticed that endogenous neurosteroids act as paracrine or autocrine factors, regulating the activity of classical nuclear steroid receptors or membrane receptors including $\mathrm{G}$ protein-coupled receptors $(109,110), \mathrm{GABA}_{\mathrm{A}}$ and T-type calcium channels (111-114) or NMDA $(115,116), \mathrm{P} 2 \mathrm{X}$ (117) and sigma receptors $(118,119)$.

\section{Neuroendocrine control of reproduction by steroids}

Another area of research that has featured strongly at the Torino meetings over the last ten years has been that of how gonadal steroids modulate the gonadotropinreleasing hormone $(\mathrm{GnRH})$ neurones that control fertility. Since 2001 much has changed in this field and this has been reflected in the Torino presentations. Firstly, the techniques used by GnRH neurone investigators have changed considerably. This has been driven primarily by the use of genetic manipulations in mice that have greatly facilitated investigation of the GnRH neurone and its network. As reflected in the 2001 meeting, the mainstay approaches of the field at that time were in situ hybridization for GnRH mRNA, one of the few direct indices of GnRH neurones at the turn of the century (120), and use of the immortalised embryonic GT1 cell lines that synthesise GnRH (121). By 2011, a range of sophisticated transgenic and cell- or receptor-specific gene mutation approaches were being used to establish the electrical properties, gene expression profiles and in vivo significance of GnRH neuroneselective receptor manipulations. The second major change in this field has been the discovery of kisspeptin. Initially discovered in humans in 2003 (122, 123), GnRH neurone investigators rapidly took up the challenge of deciphering how kisspeptin regulates fertility and this topic has been present at meetings since 2007 (124-126). 
The key gonadal steroid-GnRH neurone milestones at Torino meetings over the last 10 years have been summarised in the following sub-chapters.

\section{Understanding rapid gonadal steroid actions on GnRH neurones.}

The meeting has witnessed the gradual unfolding of how oestrogens, androgens and progesterone derivatives exert rapid, sometimes direct, actions upon GnRH neurones. At the 2001 meeting, the role of allopregnanolone on $\mathrm{GABA}_{\mathrm{A}}$-mediated effects on GnRH neurones in GT1 cells (127) and native adult GnRH neurones (128) was discussed. This was followed at the next meeting in 2003 by descriptions of how oestradiol rapidly activates specific intracellular signaling cascades in GnRH neurones, including calcium dynamics. These actions were mediated directly by ER $\beta$ expressed by GnRH neurones as well as indirectly through $\mathrm{GABA}_{\mathrm{A}}$ receptors (129, 130). This line of work was brought up to date at the most recent meeting in 2011 where studies detailing the complex, dose-dependent direct- and indirect- effects of oestradiol $(131,132)$ and androgen metabolites $(133,134)$, on GnRH neurone electrical activity were presented. Although the issue of the physiological relevance of rapid steroid actions remains unknown (135), it is clear that progesterone and androgen derivatives, as well as oestradiol itself, can exert rapid actions on mammalian GnRH neurones both directly, and indirectly through GABA and glutamatergic inputs to these cells.

Examining the role of glial cells and growth factors in the steroid regulation of GnRH neurones.

The importance of astrocytic growth factors such as TGF $\beta$ and $\beta$ FGF on the functioning of GT1 cells (121) was elucidated during the 2001 meeting. This was expanded in 2003 to document the role that oestradiol played in regulating glial production of these growth factors (136). At the same meeting, the key roles for IGF1 interactions with oestradiol in modulating adrenergic tone within the GnRH neuronal network in vivo were illustrated (137). This was to be expanded further in 2007 meeting by showing that oestradiol acts on membrane ERs on glial cells to promote progesterone synthesis that, in turn, impacts on the ability of GnRH neurones to exhibit the preovulatory surge (138). Alongside many other talks at the Torino meeting on steroid hormone-growth factor interactions, these studies have provided the impetus for considering the potentially important impact of glial cells on GnRH neurone functioning. The lack of good tools to dissect the roles of specific groups or 
regional locations of glia in vivo seems to remain a significant problem for understanding the roles of these cells beyond their normal "neuronal support roles".

\section{Defining the mechanisms of oestrogen positive and negative feedback.}

Talks presented in 2001 meeting focused upon the roles of gonadal steroids in regulating GnRH gene transcription using in situ hybrization (120) and GnRH transgenics (139), respectively. This topic moved a considerable step forward with the data presented at the 2003 meeting detailing the effects of ovariectomy and oestrogen replacement upon GnRH neurone firing rates and the potential ion channels underlying these actions (140). It would not, however, be until the 2011 meeting that the data on single cell RT-PCR allowed to define the precise ion channel subunits modulated by oestradiol in GnRH neurones $(141,142)$. The GnRH neurone firing studies in 2003 were complemented by studies showing the effects of different steroid regimens upon pulsatile GnRH secretion from hypothalamic explants (143). Although from different species, this highlighted the continuing puzzle as to why the effects of ovariectomy and oestradiol replacement on $\mathrm{GnRH}$ neurone firing rates and GnRH secretion are so dissimilar. The 2007 meeting was presented with a series of genetic and ER-specific ligand studies $(144,145)$ that defined the mechanism and types of ERs involved in the positive feedback mechanisms in mice and rats. These studies concluded that oestradiol acted on ER $\alpha$-expressing neurones in the rostral hypothalamus to activate GnRH neurones to evoke the GnRH surge (124). Other studies presented at that meeting highlighted the oestrogen-sensitivity of kisspeptin neurones (125). By the time of the 2011 meeting the promise of the oestradiolsensitive kisspeptin neurones within the GnRH neuronal network had been fulfilled with three papers $(126,146,147)$ detailing their now established key importance in different oestrogen feedback mechanisms.

Over the last 10 years, the Torino meeting has provided one focus meeting for promoting the understanding of how gonadal steroids modulate the behaviour of GnRH neurones. This is a large subject with too many active investigators to accommodate at the Torino meeting at one time. Nevertheless, those outside the field have been treated to a consistently high-quality overview of progress in the subject while GnRH neurones aficionados have had the luxury of discussing science in the delightful mid-winter setting of Torino. 
Ten years of the Torino Steroids' Meeting

\section{Interactions with classical and non classical steroid receptors}

Through the years at the International Conference on Steroids and the Nervous System, there has been much work presented on the mechanisms by which steroids may exert some of their effects. Nuclear steroid receptors (nSRs) were discovered over 50 years ago for oestrogen and were followed by discovery of specific nSRs for progestins and androgens (148). These classic nSRs are intracellular, are activated by the binding of steroids, and serve as transcription factors. Our discussions of oestrogen action in the brain via nSRs has included actions via the originally discovered $\mathrm{ER} \alpha$ and its traditional role in reproduction, but also how these actions have effects in other brain regions such as the hippocampus, to influence processes relevant for aging and related functions (149). Various effects, from form to function, of the more recently discovered ER $\beta$ have been discussed $(27,150)$, with an emphasis on integrated actions via $\operatorname{ER} \alpha$ and $\operatorname{ER} \beta$ (5). The role of progestin receptors in reproduction, and their effects as neural integrators of hormonal and environment actions, have been proposed $(151,152)$. How actions at progestin receptors may occur through steroid activation or involve other ligands, such as dopamine, is intriguing (153). At this venue, we have also discussed the role of androgens receptors in sexual differentiation, and other processes, along with how there may be actions of androgens via other nSRs, including ERbeta, as well as actions apart from nSRs (15, 16, 154-158).

More recently, it has been demonstrated that steroids bound to nSR complexes, bind hormone response elements, and have actions through co-activators, to result in changes in their rates of transcription and translation. The importance of co-regulatory factors to influence nSRs action has been discussed at our venue (159). How steroids' actions in the brain via sNRs can also involve coactivators, which modulate hormonedependent gene expression in brain and reproductive behaviour in rodents (67) and galliforms (159), and co-repressors, such as chromatin binding factors mediation of epigenetic organization of sex differences in the brain (160), has been the topic of recent symposia. Thus, as evidence has emerged regarding steroids actions via nSRs, these topics have been of ongoing interest and discussion.

This classical "genomic" mechanism of steroid action, involving the transcription of DNA and synthesis of proteins, can elicit a biological response within 10 minutes, hours or days. In addition to classical actions via nSRs, there has been an 
ongoing dialogue about non-traditional actions of steroids. Non-classical actions of steroids can occur much more rapidly ( $<10$ minutes, and even in seconds) than actions at $\mathrm{nSRs}$, in the absence of nSRs, and in the presence of inhibitors of transcription and/or translation. Non-classical, rapid steroid actions, often referred to as "nongenomic" actions of steroids, have been extensively studied over the past few decades, demonstrated for all the major classes of steroids, and are now wellrecognised. Rapid, non-classical actions of oestrogens, progestogens, and androgens and their role in various hormone-sensitive functions, have been ongoing topics of discourse at this meeting $(4,69,89,161,162)$.

An important question is which receptors mediate non-genomic actions? Several physiologically relevant membrane-associated proteins have been identified on plasma membranes suggesting the existence of specific membrane steroids receptors $(22,23,163-165)$. However, identities of some of these membrane targets remain controversial. Neurotransmitter receptors have been foci of non-genomic signaling activity of steroids. The most widely studied (and discussed) neurotransmitter targets for steroid actions have been through GABA receptors (166173). However, actions of steroids through glutamate (120, 174), dopamine (175), adrenergic (137, 176, 177), opiate (178), and sigma (179) receptors have been investigated and discussed at this meeting.

Some non-traditional effects of steroids may be downstream of actions at membrane targets. The intracellular signal transduction cascades, which mediate some behavioural effects of ovarian steroids have been discussed $(137,176)$. Some effects of steroids, such as progestagens, may be mediated in part through adenyl cyclase, Gproteins, PKA, PLC, and/or PKC pathways (180, 181). Other effects of oestrogen may be mediated through MAPK signaling, mitochondrial processes, or other intracellular pathways. (182). Extensive discussions of traditional and novel effects and mechanisms of steroids have taken place during the meetings organised in Torino. There have also been perspectives of how actions through classic nSR signaling may integrate with rapid, membrane action of steroids, and their downstream effectors $(183,184)$. The discourse to date about classic and non-traditional steroid action have been productive and will likely continue to expand the field in a substantive manner to elucidate new perspective regarding modulatory effects of steroid signalling.

\section{Neuroactive steroids as neuroprotective agents: translational research}


The role of neuroactive steroids on neurodegeneration, neuroprotection and the response of the neural tissue to injury has been a fundamental topic in the International Meeting on Steroids and Nervous System since its first edition in 2001. Since then, this field has significantly advanced and neuroactive steroids have emerged as new potential therapeutic tools to counteract neurodegenerative events.

\section{Oestradiol and neuroprotection}

By the time of the first Torino meeting extensive experimental evidence indicated that oestradiol is neuroprotective (126). However, a turning point was the publication of the results of the Women's Health Initiative (WHI) clinical trial on the effects of hormonal therapy in women $(185,186)$. The results of this study showed an increased risk of dementia and stroke in women over 65 years of age who received conjugated equine oestrogens plus medroxyprogesterone acetate (MPA) compared to women who received placebo. This finding was in contradiction with the evidence obtained in animal models of neurodegenerative diseases. Therefore, new studies have addressed in recent years the possible causes of this discrepancy. In particular, age at which hormones were administered relative to the perimenopausal transition has emerged as a critical issue. Observational studies and randomised clinical studies suggest that early initiation of hormone therapy may provide cognitive benefits, particularly to verbal memory and other hippocampus-mediated functions (187). In addition, new basic studies have shown that the neuroprotective activity of oestradiol depends on the duration of ovarian hormone deprivation (188) and is affected by age-associated modifications in the levels of other molecules, such as insulin-like growth factor-I (189).

\section{Progesterone and other neurosteroids}

Another neuroactive steroid whose neuroprotective activity has been frequently discussed in Torino meetings is progesterone. The neuroprotective activity of progesterone and its metabolites dihydroprogesterone and tetrahydroprogesterone has been characterised in the last decade (190-192). Progesterone and its metabolites promote remyelination in the CNS $(193,194)$ and the PNS (195-197). Furthermore, progesterone attenuates clinical severity, demyelination, neuronal dysfunction and axonal damage in experimental autoimmune encephalomyelitis, a well-established experimental model of multiple sclerosis (198-201) and in diabetic neuropathy (202). Progesterone is also protective after traumatic brain injury in animals (192). In addition, clinical trials have indicated a reduction in the mortality and an 
improvement of functional outcomes after traumatic brain injury in patients treated with progesterone (203).

The neuroprotective action of other neuroactive steroids has also been assessed during the last decade. Among these is allopregnanolone, whose cerebral levels are decreased in an experimental model of Niemann-Pick type $\mathrm{C}$ disease. The neonatal administration of allopregnanolone results in a delay of the onset of neurological symptoms, and a doubling the lifespan of the animals (204). Other studies have demonstrated the efficacy of treatment with dehydroepiandrosterone after spinal cord injury (205) and in diabetic neuropathy (206). Neuroactive steroids are also important endogenous modulators of mood and have therapeutic potential for the treatment of depression and anxiety disorders. Novel therapeutic strategies might either be based on synthetic derivates of endogenous 3alpha-reduced neuroactive steroids or on the modulation of neurosteroidogenic activity (207). Pregnenolone and dehydroepiandrosterone are also promising candidates for the treatment of schizophrenia $(208,209)$. Better performance on executive tasks is associated with increased plasma levels of dehydroepiandrosterone in schizophrenic patients (209) and clinical trials have demonstrated that pregnenolone is able to decrease negative symptoms and extrapyramidal side effects and to improve verbal memory, attention and working memory performance in these patients (208).

Alternatives to treatment with neuroactive steroids have been also explored in recent years. These include synthetic receptor modulators, like for instance selective oestrogen modulators (SERMs). Some SERMs have been shown to be neuroprotective and anti-inflammatory agents in experimental animal models of central neurodegeneration (210). Another alternative therapeutic strategy might be the use of pharmacological agents that increase the synthesis of endogenous neuroactive steroids within the nervous system (211). With this perspective, ligands of translocator protein (TSPO, previously known as peripheral benzodiazepine receptor (104)) may represent an interesting option (212-214). TSPO is mainly present in the mitochondrial outer membrane, where it promotes, in cooperation with steroidogenic acute regulatory protein (StAR), the translocation of cholesterol to the inner mitochondrial membrane. The mitochondrial translocation of cholesterol is a limiting step in steroidogenesis, since it allows the transformation of cholesterol into pregnenolone. Observations have shown that treatment with ligands of TSPO, like for instance Ro5-4864, exerts neuroprotective effects in aged peripheral nervous system 
Ten years of the Torino Steroids' Meeting

(215), in peripheral nerve during diabetes (216) and in CNS after neuronal injury (217). A similar approach has been obtained with a ligand of liver X receptors. Indeed, treatment of diabetic animals with a synthetic ligand of these receptors (i.e., GW3965) results in an increase of neuroactive steroidoigenesis in the sciatic nerve which is associated with neuroprotective effects (218).

\section{Perspectives for the future}

During the last decade several studies have shown that pathological events have an important impact on neuroactive steroid levels in nervous tissues. Changes in neurosteroid biosynthesis or in neurosteroid levels in the brain, spinal cord or peripheral nerves have been detected under different pathological conditions, including experimental models of diabetes (219-221), hereditary peripheral neuropathy (219), peripheral nerve injury (222), spinal cord injury (223, 224), multiple sclerosis (225, 226), autism (227), and Parkinson's disease (228, 229). Neuroactive steroid levels are also modified in the human brain under pathological conditions, including Alzheimer's disease, Parkinson's disease, multiple sclerosis and hepatic encephalopathy $(97,230-235)$. To develop adequate therapeutic tools based on neuroactive steroids (212-214) it would be necessary to increase our knowledge on the specific regional and temporal changes that occur in neurosteroid levels in the human brain at different phases of neurodegenerative diseases and during affective disorders. In addition, it would be also necessary to determine the implications of such changes for the manifestation and outcome of the pathological condition.

Another important issue is that different pathologies of the central and peripheral nervous system show sex differences in their incidence, symptomatology and/or neurodegenerative outcome (236). Interestingly, the levels of neuroactive steroids in the CNS and PNS under pathological conditions also show sex differences $(219,221,224-226,237,238)$. In addition, the nervous system of males and females show different responses to neuroactive steroids. Therefore, it would be important to explore with detail the interaction of sex with neurosteroid levels and neurosteroid actions to develop adequate sex-specific neuroprotective strategies. 
Ten years of the Torino Steroids' Meeting

\section{Acknowledgments.}

We want to acknowledge here Institutions and private companies that supported the organization of the 6th International meeting on Steroids and Nervous System. In particular, we would like to acknowledge the financial support of the University of Milano. The International Brain Research Organization (IBRO), the International Neuroendocrine Federation (INF), the Italian Society for Neuroscience (SINS), and the Italian Group of Neuromorphology (GISN) generously supported fellowships for young researchers attending the meeting. A few private Italian companies supported our meeting, namely DBA, Nikon, and Rekordata. Finally, we want to thank WileyBlackwell and all the staff of the Journal of Neuroendocrinology that hosted this special issue.

Information about this series of conferences is available at a dedicated website http://www.dafml.unito.it/anatomy/panzica/neurosteroids/index.html, where the extended abstracts of all the editions of the meeting are available for downloading.

For part of the researches summarised in this paper, the financial support of Fondazione San Paolo (Neuroscience Project) to GCP and RCM, Fondazione Cavalieri-Ottolenghi to GCP, Fondazione Italiana Sclerosi Multipla (2010/23) to RCM, and Association Ti'toine (Normandie, France) to AGM-N are gratefully acknowledged 
Ten years of the Torino Steroids' Meeting

\section{Legend to the figure}

Fig. 1 - Participants at the $6^{\text {th }}$ International Meeting on Steroids and Nervous System, Torino, February 2011. 
Ten years of the Torino Steroids' Meeting

\section{References}

1. Panzica GC, Ottinger MA. Action of environmental estrogens on neural circuits and behavior (Special Issue). Brain Res Bull. 2005; 65: 185-273.

2. McCarthy MM, Todd BJ, Amateau SK. Estradiol modulation of astrocytes and the establishment of sex differences in the brain. Ann N Y Acad Sci. 2003; 1007: 28397.

3. Arnold AP, Rissman EF, De Vries GJ. Two perspectives on the origin of sex differences in the brain. Ann N Y Acad Sci. 2003; 1007: 176-88.

4. Balthazart J, Cornil CA, Taziaux M, Charlier TD, Baillien M, Ball GF. Rapid changes in production and behavioral action of estrogens. Neuroscience. 2006; 138: 783-91.

5. Kudwa AE, Michopoulos V, Gatewood JD, Rissman EF. Roles of estrogen receptors alpha and beta in differentiation of mouse sexual behavior. Neuroscience. 2006; 138: 921-8.

6. Bao AM, Meynen G, Swaab DF. The stress system in depression and neurodegeneration: Focus on the human hypothalamus. Brain Res Rev. 2008; 57: 531-53.

7. Todd BJ, Merhi ZO, Shu J, Etgen AM, Neal-Perry GS. Hypothalamic insulinlike growth factor-I receptors are necessary for hormone-dependent luteinizing hormone surges: implications for female reproductive aging. Endocrinology. 2010; 151: $1356-66$.

8. Schlinger BA, Remage-Healey L. Neurosteroidogenesis: Insights from Studies of Songbirds. J Neuroendocrinol. 2011.

9. Henderson VW, Brinton RD. Menopause and mitochondria: windows into estrogen effects on Alzheimer's disease risk and therapy. Prog Brain Res. 2010; 182: 77-96.

10. Phoenix CH, Goy RW, Gerall AA, Young WC. Organizing action of prenatally administered testosterone propionate on the tissues mediating mating behavior in the female guinea pig. Endocrinology. 1959; 65: 369-82.

11. Arnold AP, Chen X. What does the "four core genotypes" mouse model tell us about sex differences in the brain and other tissues? Front Neuroendocrinol. 2009; 30: $1-9$.

12. Budefeld T, Tobet SA, Majdic G. Steroidogenic factor 1 and the central nervous system. J Neuroendocrinol. 2011. 
13. Pierman S, Sica M, Allieri F, Viglietti-Panzica C, Panzica GC, Bakker J. Activational effects of estradiol and dihydrotestosterone on social recognition and the arginine-vasopressin immunoreactive system in male mice lacking a functional aromatase gene. Horm Behav. 2008; 54: 98-106.

14. Plumari L, Viglietti Panzica C, Allieri F, Honda S, Harada N, Absil P, Balthazar J, Panzica GC. Changes in the Arginine-Vasopressin Immunoreactive Systems in Male Mice Lacking a Functional Aromatase Gene. J Neuroendocrinol. 2002; 14: 971-8.

15. Bodo C. A role for the androgen receptor in the sexual differentiation of the olfactory system in mice. Brain Res Rev. 2008; 57: 321-31.

16. Martini M, Di Sante G, Collado P, Pinos H, Guillamon A, Panzica GC. Androgen receptors are required for full masculinization of nitric oxide synthase system in rat limbic-hypothalamic region. Horm Behav. 2008; 54: 557-64.

17. Panzica GC, Allieri F, Bo E, Collado P, Bakker J, Viglietti-Panzica C. Androgens and development of the BST parvocellular vasopressin system. Trab Inst Cajal. 2009; LXXXII: 78-9.

18. Ahmed EI, Zehr JL, Schulz KM, Lorenz BH, DonCarlos LL, Sisk CL. Pubertal hormones modulate the addition of new cells to sexually dimorphic brain regions. Nat Neurosci. 2008; 11: 995-7.

19. Bodo C, Kudwa AE, Rissman EF. Both estrogen receptor-alpha and -beta are required for sexual differentiation of the anteroventral periventricular area in mice. Endocrinology. 2006; 147: 415-20.

20. Juntti SA, Tollkuhn J, Wu MV, Fraser EJ, Soderborg T, Tan S, Honda S, Harada N, Shah NM. The androgen receptor governs the execution, but not programming, of male sexual and territorial behaviors. Neuron. 2010; 66: 260-72.

21. Ogawa S, Chester AE, Hewitt SC, Walker VR, Gustafsson JÅ, Smithies O, Korach KS, Pfaff DW. Abolition of male sexual behaviors in mice lacking estrogen receptors alpha and beta ( $\alpha \beta E R K O)$. Proc Natl Acad Sci U S A. 2000; 97: 14737-41.

22. Kelly MJ, Qiu J, Ronnekleiv OK. Estrogen modulation of G-protein-coupled receptor activation of potassium channels in the central nervous system. Ann NY Acad Sci. 2003; 1007: 6-16.

23. Kelly MJ, Ronnekleiv OK. Membrane-initiated estrogen signaling in hypothalamic neurons. Mol Cell Endocrinol. 2008; 290: 14-23. 
24. Balthazart J, Ball GF. Is brain estradiol a hormone or a neurotransmitter? Trends Neurosci. 2006; 29: 241-9.

25. Schwarz JM, Liang SL, Thompson SM, McCarthy MM. Estradiol induces hypothalamic dendritic spines by enhancing glutamate release: a mechanism for organizational sex differences. Neuron. 2008; 58: 584-98.

26. Kudwa AE, Bodo C, Gustafsson JA, Rissman EF. A previously uncharacterized role for estrogen receptor beta: defeminization of male brain and behavior. Proc Natl Acad Sci U S A. 2005; 102: 4608-12.

27. Handa RJ, Ogawa S, Wang JM, Herbison AE. Roles for estrogen receptor beta in adult brain function. $J$ Neuroendocrinol. 2011.

28. Amateau SK, McCarthy MM. Induction of PGE2 by estradiol mediates developmental masculinization of sex behavior. Nat Neurosci. 2004; 7: 643-50.

29. Todd BJ, Schwarz JM, McCarthy MM. Prostaglandin-E2: a point of divergence in estradiol-mediated sexual differentiation. Horm Behav. 2005; 48: 512 21.

30. Bakker J, Honda S, Harada N, Balthazart J. The aromatase knockout (ArKO) mouse provides new evidence that estrogens are required for the development of the female brain. Ann N Y Acad Sci. 2003; 1007: 251-62.

31. Bakker J, Baum MJ. Role for estradiol in female-typical brain and behavioral sexual differentiation. Front Neuroendocrinol. 2008; 29: 1-16.

32. Matsuda KI, Mori H, Nugent BM, Pfaff DW, McCarthy MM, Kawata M. Histone Deacetylation during Brain Development Is Essential for Permanent Masculinization of Sexual Behavior. Endocrinology. 2011; 152: 2760-7.

33. Tsai HW, Grant PA, Rissman EF. Sex differences in histone modifications in the neonatal mouse brain. Epigenetics. 2009; 4: 47-53.

34. McCarthy MM, Auger AP, Bale TL, De Vries GJ, Dunn GA, Forger NG, Murray EK, Nugent BM, Schwarz JM, Wilson ME. The epigenetics of sex differences in the brain. J Neurosci. 2009; 29: 12815-23.

35. Nugent BM, Schwarz JM, McCarthy MM. Hormonally mediated epigenetic changes to steroid receptors in the developing brain: Implications for sexual differentiation. Horm Behav. 2011; 59: 338-44.

36. Schwarz JM, Nugent BM, McCarthy MM. Developmental and hormoneinduced epigenetic changes to estrogen and progesterone receptor genes in brain are dynamic across the life span. Endocrinology. 2010; 151: 4871-81. 
37. De Vries GJ. Minireview: Sex differences in adult and developing brains: compensation, compensation, compensation. Endocrinology. 2004; 145: 1063-8.

38. Döhler KD, Hines M, Coquelin A, Davis FC, Shryne JE, Gorski RA. Pre- and postnatal influence of diethylstilboestrol on differentiation of the sexually dimorphic nucleus in the preoptic area of the female rat brain. Neuroendocrinol Lett. 1982; 4: $361-5$.

39. Bogic L, Gerlach JL, McEwen BS. The ontogeny of sex differences in estrogen-induced progesterone receptors in rat brain. Endocrinology. 1988; 122: 2735-41.

40. Colborn T, vom Saal FS, Soto AM. Developmental effects of endocrinedisrupting chemicals in wildlife and humans. Environ Health Perspect. 1993; 101: 378-84.

41. Bern HA, Blair P, Brasseur S, Colborn T, Cunha GR, Davis W, Dohler KD, Fox G, Fry M, Gray E, Green R, Hines M, Kubiak TJ, McLachlan J, Myers J, P., Peterson RE, Reijnders PJH, Soto AM, Van Der Kraak G, vom Saal FS, Whitten P. Statement from the Work Session on Chemically-Induced Alterations in Sexual Development: The Wildlife/Human Connection. In: Colborn T, Clement C, eds. Chemically-induced alterations in sexual and functional development: the wildlife/human connection. Princeton, New Jersey: Princeton Scientific Publishing Co., Inc. 1992: 1-8.

42. Lephart ED, Lund TD, Horvath TL. Brain androgen and progesterone metabolizing enzymes: biosynthesis, distribution and function. Brain Res Rev. 2001; 37: $25-37$.

43. Lephart ED, Adlercreutz H, Lund TD. Dietary soy phytoestrogen effects on brain structure and aromatase in Long-Evans rats. Neuroreport. 2001; 12: 3451-5.

44. Lephart ED, West TW, Weber KS, Rhees RW, Setchell KDR, Adlercreutz H, Lund TD. Neurobehavioral effects of dietary soy phytoestrogens. Neurotoxicol Teratol. 2002; 24: 5 - 16 .

45. McLachlan JA, Guillette LJ, Jr., Iguchi T, Toscano WAj. Environmental Hormones: The scientific basis of endocrine disruption New York: NYAS, 2001.

46. Bauer R, Colborn T, Palanza P, Parmigiani S, Vom Saal FS. Endocrine Disruptors. Environ Health Perspect (Special Issue). 2002; 110 (Suppl.3): 335-449.

47. Alò R, Facciolo RM, Madeo M, Giusi G, Carelli A, Canonaco M. Effects of the xenoestrogen bisphenol $\mathrm{A}$ in diencephalic regions of the teleost fish Coris julis 
occur preferentially via distinct somatostatin receptor subtypes. Brain Res Bull. 2005; 65: $267-73$.

48. Viglietti-Panzica C, Montoncello B, Mura E, Pessatti M, Panzica GC. Organizational effects of diethylstilbestrol on brain vasotocin and sexual behavior in male quail. Brain Res Bull. 2005; 65: 225-33.

49. Panzica GC, Mura E, Pessatti M, Viglietti Panzica C. Early embryonic administration of xenoestrogens alters vasotocin system and male sexual behavior of the Japanese quail. Domest Anim Endocrinol. 2005; 29: 436-45.

50. Ottinger MA, Wu JM, Hazelton JL, Abdelnabi MA, Thompson N, Quinn ML, Donoghue D, F. S, Ruscio M, Beavers J, Jaber M. Assessing the consequences of the pesticide methoxychlor: neuroendocrine and behavioral measures as indicators of biological impact of an estrogenic environmental chemical. Brain Res Bull. 2005; 65: 199-210.

51. Halldin K, Axelsson J, Brunstrom B. Effects of endocrine modulators on sexual differentiation and reproductive function in male Japanese quail. Brain Res Bull. 2005; 65: 211-8.

52. Laviola G, Gioiosa L, Adriani W, Palanza P. d-Amphetamine-related reinforcing effects are reduced in mice exposed prenatally to estrogenic endocrine disruptors. Brain Res Bull. 2005; 65: 235-40.

53. Della Seta D, Minder I, Dessi-Fulgheri F, Farabollini F. Bisphenol-A exposure during pregnancy and lactation affects maternal behavior in rats. Brain Res Bull. 2005; 65: 255-60.

54. Porrini S, Belloni V, Seta DD, Farabollini F, Giannelli G, Dessi-Fulgheri F. Early exposure to a low dose of bisphenol A affects socio-sexual behavior of juvenile female rats. Brain Res Bull. 2005; 65: 261-6.

55. Razzoli M, Valsecchi P, Palanza P. Chronic exposure to low doses bisphenol A interferes with pair-bonding and exploration in female Mongolian gerbils. Brain Res Bull. 2005; 65: 249-54.

56. Mussi P, Ciana P, Raviscioni M, Villa R, Regondi S, Agradi E, Maggi A, Lorenzo DD. Activation of brain estrogen receptors in mice lactating from mothers exposed to DDT. Brain Res Bull. 2005; 65: 241-7.

57. Bu L-H, Lephart ED. Effects of dietary phytoestrogens on core body temperature during the estrous cycle and pregnancy. Brain Res Bull. 2005; 65: 21923. 
58. Lephart ED, Setchell KDR, Lund TD. Phytoestrogens: Hormonal action and brain plasticity. Brain Res Bull. 2005; 65: 193-8.

59. Mukai H, Takata N, Ishii HT, Tanabe N, Hojo Y, Furukawa A, Kimoto T, Kawato S. Hippocampal synthesis of estrogens and androgens which are paracrine modulators of synaptic plasticity: synaptocrinology. Neuroscience. 2006; 138: 757 64.

60. Gu Q, Korach KS, Moss RL. Rapid action of 17beta-estradiol on kainateinduced currents in hippocampal neurons lacking intracellular estrogen receptors. Endocrinology. 1999; 140: 660-6.

61. Shibuya K, Takata N, Hojo Y, Furukawa A, Yasumatsu N, Kimoto T, Enami T, Suzuki K, Tanabe N, Ishii H, Mukai H, Takahashi T, Hattori TA, Kawato S. Hippocampal cytochrome P450s synthesize brain neurosteroids which are paracrine neuromodulators of synaptic signal transduction. Biochim Biophys Acta. 2003; 1619: 301-16.

62. Kawato S. Endocrine disrupters as disrupters of brain function: a neurosteroid viewpoint. Environ Sci. 2004; 11: 1-14.

63. Ogiue-Ikeda M, Tanabe N, Mukai H, Hojo Y, Murakami G, Tsurugizawa T, Takata N, Kimoto T, Kawato S. Rapid modulation of synaptic plasticity by estrogens as well as endocrine disrupters in hippocampal neurons. Brain Res Rev. 2008; 57: 363-75.

64. Di Lorenzo D, Rando G, Ciana P, Maggi A. Molecular imaging, an innovative methodology for whole-body profiling of endocrine disrupter action. Toxicol Sci. 2008; 106: 304-11.

65. Patisaul HB, Polston EK. Influence of endocrine active compounds on the developing rodent brain. Brain Res Rev. 2008; 57: 352-62.

66. Ottinger MA, Lavoie E, Thompson N, Barton A, Whitehouse K, Abdelnabi M, Quinn MJ, Jr., Panzica GC, Viglietti-Panzica C. Neuroendocrine and Behavioral Effects of Embryonic Exposure to Endocrine Disrupting Chemicals in Birds. Brain Res Rev. 2008; 57: 376-85.

67. Tetel MJ. Modulation of steroid action in the central and peripheral nervous systems by nuclear receptor coactivators. Psychoneuroendocrinology. 2009; 34 (Suppl.2): 9-19. 
68. Palanza P, Gioiosa L, vom Saal FS, Parmigiani S. Effects of developmental exposure to bisphenol A on brain and behavior in mice. Environ Res. 2008; 108: 1507.

69. Frye C, Bo E, Calamandrei G, Calza L, Dessi-Fulgheri F, Fernandez M, Fusani L, Kah O, Kajta M, Le Page Y, Patisaul HB, Venerosi A, Wojtowicz AK, Panzica GC. Endocrine Disrupters: A Review of Some Sources, Effects, and Mechanisms of Actions on Behavior and Neuroendocrine Systems. $J$ Neuroendocrinol. 2011.

70. Panzica GC, Viglietti-Panzica C, Mura E, Quinn Jr MJ, Palanza P, Ottinger MA. Effects of xenoestrogens on the differentiation of behaviorally relevant neural circuits. Front Neuroendocrinol. 2007; 28: 179-200.

71. Panzica GC, Mura E, Miceli D, Martini M, Gotti S, Viglietti Panzica C. Effects of xenoestrogens on the differentiation of behaviorally-relevant neural circuits in higher vertebrates. In: Vaudry H, Rubois E, Coast GM, Vallarino M, eds. Trends in Comparative Endocrinology and Neurobiology. New York, NY: New York Academy of Sciences 2009: 271-8.

72. Panzica GC, Bo E, Martini MA, Miceli D, Mura E, Viglietti-Panzica C, Gotti S. Neuropeptides and Enzymes are Targets for the Action of Endocrine Disrupting Chemicals in the Vertebrate Brain. J Toxicol Environ Health B Crit Rev. 2011; 14: 449-72.

73. Bateman HL, Patisaul HB. Disrupted female reproductive physiology following neonatal exposure to phytoestrogens or estrogen specific ligands is associated with decreased GnRH activation and kisspeptin fiber density in the hypothalamus. Neurotoxicology. 2008; 29: 988-97.

74. Bellingham M, Fowler PA, Amezaga MR, Rhind SM, Cotinot C, MandonPepin B, Sharpe RM, Evans NP. Exposure to a complex cocktail of environmental endocrine-disrupting compounds disturbs the kisspeptin/GPR54 system in ovine hypothalamus and pituitary gland. Environ Health Perspect. 2009; 117: 1556-62.

75. Dickerson SM, Cunningham SL, Patisaul HB, Woller MJ, Gore AC. Endocrine disruption of brain sexual differentiation by developmental PCB exposure. Endocrinology. 2011; 152: 581-94.

76. Miceli D, Bo E, Palanza P, Franceschini I, Panzica GC. Effects of BisphenolA (BPA) in the hypothalamic nuclei that control puberty, reproduction and sexual behavior in a murine model. Trab Inst Cajal. 2011; 83: 194-5. 
Ten years of the Torino Steroids' Meeting

77. Patisaul HB, Todd KL, Mickens JA, Adewale HB. Impact of neonatal exposure to the ERalpha agonist PPT, bisphenol-A or phytoestrogens on hypothalamic kisspeptin fiber density in male and female rats. Neurotoxicology. 2009; 30: $350-7$.

78. Mura E, Barale C, Quinn Jr MJ, Panzica GC, Ottinger MA, Viglietti Panzica C. Organizational Effects of DDE on Brain Vasotocin System in Male Japanese Quail. Neurotoxicology. 2009; 30: 479-84.

79. Viglietti-Panzica C, Mura E, Panzica GC. Effects of early embryonic exposure to genistein on male copulatory behavior and vasotocin system of Japanese quail. Horm Behav. 2007; 51: 355-63.

80. Cheshenko K, Pakdel F, Segner H, Kah O, Eggen RI. Interference of endocrine disrupting chemicals with aromatase CYP19 expression or activity, and consequences for reproduction of teleost fish. Gen Comp Endocrinol. 2008; 155: 31 62.

81. Le Page Y, Scholze M, Kah O, Pakdel F. Assessment of xenoestrogens using three distinct estrogen receptors and the zebrafish brain aromatase gene in a highly responsive glial cell system. Environ Health Perspect. 2006; 114: 752-8.

82. Le Page Y, Vosges M, Servili A, Brion F, Kah O. Neuroendocrine effects of endocrine disruptors in teleost fish. J Toxicol Environ Health B Crit Rev. 2011; 14: 370-86.

83. Curras-Collazo MC. Nitric oxide signaling as a common target of organohalogens and other neuroendocrine disruptors. J Toxicol Environ Health B Crit Rev. 2011; 14: 495-536.

84. Martini M, Miceli D, Gotti S, Viglietti-Panzica C, Fissore E, Palanza P, Panzica GC. Effects of perinatal administration of bisphenol A on the neuronal nitric oxide synthase expressing system in the hypothalamus and limbic system of CD1 mice. J Neuroendocrinol. 2010; 22: 1004-12.

85. Vom Saal FS. Bisphenol a eliminates brain and behavior sex dimorphisms in mice: how low can you go? Endocrinology. 2006; 147: 3679-80.

86. Tena-Sempere M. Kisspeptin/GPR54 system as potential target for endocrine disruption of reproductive development and function. Int J Androl. 2010; 33: 360-8.

87. Decherf S, Demeneix BA. The obesogen hypothesis: a shift of focus from the periphery to the hypothalamus. J Toxicol Environ Health B Crit Rev. 2011; 14: 42348. 
88. MacLusky NJ, Hajszán T, Leranth C. The environmental estrogen bisphenolA inhibits estradiol-induced hippocampal synaptogenesis. Environ Health Perspect. 2005; 113: 675-9.

89. MacLusky NJ, Hajszan T, Prange-Kiel J, Leranth C. Androgen modulation of hippocampal synaptic plasticity. Neuroscience. 2006; 138: 957-65.

90. Hajszan T, Leranth C. Bisphenol A interferes with synaptic remodeling. Front Neuroendocrinol. 2010; 31: 519-30.

91. $\mathrm{Xu} \mathrm{XH,} \mathrm{Zhang} \mathrm{J,} \mathrm{Wang} \mathrm{YM,} \mathrm{Ye} \mathrm{YP,} \mathrm{Luo} \mathrm{QQ.} \mathrm{Perinatal} \mathrm{exposure} \mathrm{to}$ bisphenol-A impairs learning-memory by concomitant down-regulation of N-methyld-aspartate receptors of hippocampus in male offspring mice. Horm Behav. 2010.

92. Baulieu EE, Robel P, Schumacher M. Neurosteroids. A new regulatory function in the nervous system Totowa, NJ: Humana Press, 1999.

93. Corpechot C, Robel P, Axelson M, Sjovall J, Baulieu EE. Characterization and measurement of dehydroepiandrosterone sulfate in rat brain. Proc Natl Acad Sci U S A. 1981; 78: 4704-7.

94. Corpechot C, Synguelakis M, Talha S, Axelson M, Sjovall J, Vihko R, Baulieu EE, Robel P. Pregnenolone and its sulfate ester in the rat brain. Brain Res. 1983; 270: 119-25.

95. Compagnone NA, Mellon SH. Neurosteroids: biosynthesis and function of these novel neuromodulators. Front Neuroendocrinol. 2000; 21: 1-56.

96. Mensah-Nyagan AG, Do-Rego JL, Beaujean D, Luu-The V, Pelletier G, Vaudry H. Neurosteroids: expression of steroidogenic enzymes and regulation of steroid biosynthesis in the central nervous system. Pharmacol Rev. 1999; 51: 63-81.

97. Schumacher M, Weill-Engerer S, Liere P, Robert F, Franklin RJ, GarciaSegura LM, Lambert JJ, Mayo W, Melcangi RC, Parducz A, Suter U, Carelli C, Baulieu EE, Akwa Y. Steroid hormones and neurosteroids in normal and pathological aging of the nervous system. Prog Neurobiol. 2003; 71: 3-29.

98. Mellon SH, Griffin LD, Compagnone NA. Biosynthesis and action of neurosteroids. Brain Res Rev. 2001; 37: 3-12.

99. Mensah-Nyagan AG, Beaujean D, Luu-The V, Pelletier G, Vaudry H. Anatomical and biochemical evidence for the synthesis of unconjugated and sulfated neurosteroids in amphibians. Brain Res Rev. 2001; 37: 13-24.

100. Stoffel-Wagner B. Neurosteroid biosynthesis in the human brain and its clinical implications. Ann N Y Acad Sci. 2003; 1007: 64-78. 
101. Guarneri P, Cascio C, Russo D, D'Agostino S, Drago G, Galizzi G, De Leo G, Piccoli F, Guarneri M, Guarneri R. Neurosteroids in the retina: neurodegenerative and neuroprotective agents in retinal degeneration. Ann N Y Acad Sci. 2003; 1007: 11728.

102. Melcangi RC, Mensah-Nyagan AG. Neuroprotective effects of neuroactive steroids in the spinal cord and peripheral nerves. J Mol Neurosci. 2006; 28: 1-102.

103. Lavaque E, Sierra A, Azcoitia I, Garcia-Segura LM. Steroidogenic acute regulatory protein in the brain. Neuroscience. 2006; 138: 741-7.

104. Papadopoulos V, Lecanu L, Brown RC, Han Z, Yao ZX. Peripheral-type benzodiazepine receptor in neurosteroid biosynthesis, neuropathology and neurological disorders. Neuroscience. 2006; 138: 749-56.

105. Melcangi RC, Mensah-Nyagan AG. Neurosteroids. Neurochem Int. 2008; 52: 503-620.

106. Melcangi RC, Garcia-Segura LM, Panzica GC. Neuroactive Steroids: Focus on Human Brain. Neuroscience. 2011; 191: 1-158.

107. Melcangi RC, Garcia-Segura LM, Mensah-Nyagan AG. Neuroactive steroids: state of the art and new perspectives. Cell Mol Life Sci. 2008; 65: 777-97.

108. Schaeffer V, Meyer L, Patte-Mensah C, Mensah-Nyagan AG. Progress in dorsal root ganglion neurosteroidogenic activity: basic evidence and pathophysiological correlation. Prog Neurobiol. 2010; 92: 33-41.

109. Zhu Y, Rice CD, Pang Y, Pace M, Thomas P. Cloning, expression, and characterization of a membrane progestin receptor and evidence it is an intermediary in meiotic maturation of fish oocytes. Proc Natl Acad Sci U S A. 2003; 100: 2231-6.

110. Zhu Y, Bond J, Thomas P. Identification, classification, and partial characterization of genes in humans and other vertebrates homologous to a fish membrane progestin receptor. Proc Natl Acad Sci U S A. 2003; 100: 2237-42.

111. Belelli D, Lambert JJ. Neurosteroids: endogenous regulators of the GABA(A) receptor. Nat Rev Neurosci. 2005; 6: 565-75.

112. Hosie AM, Wilkins ME, da Silva HM, Smart TG. Endogenous neurosteroids regulate GABAA receptors through two discrete transmembrane sites. Nature. 2006; 444: 486-9.

113. Majewska MD. Neurosteroids: endogenous bimodal modulators of the GABAA receptor. Mechanism of action and physiological significance. Prog Neurobiol. 1992; 38: 379-95. 
114. Pathirathna S, Brimelow BC, Jagodic MM, Krishnan K, Jiang X, Zorumski CF, Mennerick S, Covey DF, Todorovic SM, Jevtovic-Todorovic V. New evidence that both T-type calcium channels and GABAA channels are responsible for the potent peripheral analgesic effects of 5alpha-reduced neuroactive steroids. Pain. 2005; 114: 429-43.

115. Bowlby MR. Pregnenolone sulfate potentiation of N-methyl-D-aspartate receptor channels in hippocampal neurons. Mol Pharmacol. 1993; 43: 813-9.

116. Wu FS, Gibbs TT, Farb DH. Pregnenolone sulfate: a positive allosteric modulator at the N-methyl-D-aspartate receptor. Mol Pharmacol. 1991; 40: 333-6.

117. De Roo M, Rodeau JL, Schlichter R. Dehydroepiandrosterone potentiates native ionotropic ATP receptors containing the P2X2 subunit in rat sensory neurones. J Physiol. 2003; 552: 59-71.

118. Maurice T, Gregoire C, Espallergues J. Neuro(active)steroids actions at the neuromodulatory sigma1 (sigma1) receptor: biochemical and physiological evidences, consequences in neuroprotection. Pharmacol Biochem Behav. 2006; 84: 581-97.

119. Monnet FP, Mahe V, Robel P, Baulieu EE. Neurosteroids, via sigma receptors, modulate the $[3 \mathrm{H}]$ norepinephrine release evoked by $\mathrm{N}$-methyl-D-aspartate in the rat hippocampus. Proc Natl Acad Sci U S A. 1995; 92: 3774-8.

120. Gore AC. Gonadotropin-releasing hormone neurons, NMDA receptors, and their regulation by steroid hormones across the reproductive life cycle. Brain Res Rev. 2001; 37: 235-48.

121. Melcangi RC, Cavarretta I, Magnaghi V, Martini L, Galbiati M. Interactions between growth factors and steroids in the control of LHRH-secreting neurons. Brain Res Rev. 2001; 37: 223-34.

122. de Roux N, Genin E, Carel JC, Matsuda F, Chaussain JL, Milgrom E. Hypogonadotropic hypogonadism due to loss of function of the KiSS1-derived peptide receptor GPR54. Proc Natl Acad Sci U S A. 2003; 100: 10972-6.

123. Seminara SB, Messager S, Chatzidaki EE, Thresher RR, Acierno JS, Jr., Shagoury JK, Bo-Abbas Y, Kuohung W, Schwinof KM, Hendrick AG, Zahn D, Dixon J, Kaiser UB, Slaugenhaupt SA, Gusella JF, O'Rahilly S, Carlton MB, Crowley WF, Jr., Aparicio SA, Colledge WH. The GPR54 gene as a regulator of puberty. $N$ Engl J Med. 2003; 349: 1614-27. 
124. Herbison AE. Estrogen positive feedback to gonadotropin-releasing hormone $(\mathrm{GnRH})$ neurons in the rodent: The case for the rostral periventricular area of the third ventricle (RP3V). Brain Res Rev. 2008; 57: 277-87.

125. Smith JT. Kisspeptin signalling in the brain: Steroid regulation in the rodent and ewe. Brain Res Rev. 2008; 57: 288-98.

126. Garcia-Galiano D, Pinilla L, Tena-Sempere M. Sex Steroids and the Control of the Kiss1 System: Developmental Roles and Major Regulatory Actions. J Neuroendocrinol. 2011.

127. El-Etr M, Akwa Y, Baulieu EE, Schumacher M. The neuroactive steroid pregnenolone sulfate stimulates the release of gonadotropin-releasing hormone from GT1-7 hypothalamic neurons, through N-methyl-D-aspartate receptors. Endocrinology. 2006; 147: 2737-43.

128. Sim JA, Skynner MJ, Herbison AE. Direct Regulation of Postnatal GnRH Neurons by the Progesterone Derivative Allopregnanolone in the Mouse. Endocrinology. 2001; 142: 4448-53.

129. Abraham IM, Han SK, Todman MG, Korach KS, Herbison AE. Estrogen receptor beta mediates rapid estrogen actions on gonadotropin-releasing hormone neurons in vivo. J Neurosci. 2003; 23: 5771-7.

130. Romano N, Lee K, Abraham IM, Jasoni CL, Herbison AE. Nonclassical estrogen modulation of presynaptic GABA terminals modulates calcium dynamics in gonadotropin-releasing hormone neurons. Endocrinology. 2008; 149: 5335-44.

131. Moenter SM, Chu Z. Rapid non-genomic effects of oestradiol on GnRH neurons. J Neuroendocrinol. 2011.

132. Chu Z, Andrade J, Shupnik MA, Moenter SM. Differential regulation of gonadotropin-releasing hormone neuron activity and membrane properties by acutely applied estradiol: dependence on dose and estrogen receptor subtype. J Neurosci. 2009; 29: 5616-27.

133. Oberlander JG, Porter DM, Penatti CA, Henderson LP. Anabolic Androgenic Steroid Abuse: Multiple Mechanisms of Regulation of Gabaergic Synapses in Neuroendocrine Control Regions of the Rodent Forebrain. J Neuroendocrinol. 2011. 134. Penatti CA, Davis MC, Porter DM, Henderson LP. Altered GABAA receptormediated synaptic transmission disrupts the firing of gonadotropin-releasing hormone neurons in male mice under conditions that mimic steroid abuse. J Neurosci. 2010; 30: $6497-506$. 
135. Herbison AE. Rapid actions of oestrogen on gonadotropin-releasing hormone neurons; from fantasy to physiology? J Physiol. 2009; 587: 5025-30.

136. Galbiati M, Saredi S, Melcangi RC. Steroid hormones and growth factors act in an integrated manner at the levels of hypothalamic astrocytes: a role in the neuroendocrine control of reproduction. Ann N Y Acad Sci. 2003; 1007: 162-8.

137. Etgen AM. Ovarian steroid and growth factor regulation of female reproductive function involves modification of hypothalamic alpha 1-adrenoceptor signaling. Ann N Y Acad Sci. 2003; 1007: 153-61.

138. Micevych P, Soma KK, Sinchak K. Neuroprogesterone: Key to estrogen positive feedback? Brain Res Rev. 2008; 57: 470-80.

139. Thanky NR, Slater R, Herbison AE. Sex differences in estrogen-dependent transcription of gonadotropin-releasing hormone $(\mathrm{GnRH})$ gene revealed in $\mathrm{GnRH}$ transgenic mice. Endocrinology. 2003; 144: 3351-8.

140. Moenter SM, Defazio RA, Straume M, Nunemaker CS. Steroid regulation of GnRH neurons. Ann N Y Acad Sci. 2003; 1007: 143-52.

141. Ronnekleiv OK, Bosch MA, Zhang C. Regulation of endogenous conductances in GnRH neurons by estrogens. Brain Res. 2010; 1364: 25-34.

142. Ronnekleiv OK, Bosch MA, Zhang C. 17beta-Estradiol Regulation of GnRH neuronal excitability. J Neuroendocrinol. 2011.

143. Matagne V, Lebrethon MC, Gerard A, Bourguignon JP. In vitro paradigms for the study of GnRH neuron function and estrogen effects. Ann N Y Acad Sci. 2003; 1007: $129-42$.

144. Roa J, Vigo E, Castellano JM, Gaytan F, Navarro VM, Aguilar E, Dijcks FA, Ederveen AG, Pinilla L, van Noort PI, Tena-Sempere M. Opposite roles of estrogen receptor (ER)-alpha and ERbeta in the modulation of luteinizing hormone responses to kisspeptin in the female rat: implications for the generation of the preovulatory surge. Endocrinology. 2008; 149: 1627-37.

145. Wintermantel TM, Campbell RE, Porteous R, Bock D, Grone HJ, Todman MG, Korach KS, Greiner E, Perez CA, Schutz G, Herbison AE. Definition of estrogen receptor pathway critical for estrogen positive feedback to gonadotropinreleasing hormone neurons and fertility. Neuron. 2006; 52: 271-80.

146. Clarkson J, Herbison AE. Dual phenotype kisspeptin-dopamine neurones of the rostral periventricular area of the third ventricle project to gonadotrophinreleasing hormone neurones. J Neuroendocrinol. 2011; 23: 293-301. 
147. Khan AR, Kauffman AS. The Role of Kisspeptin and RFRP-3 Neurons in the Circadian-Timed Preovulatory Luteinizing Hormone Surge. J Neuroendocrinol. 2011. 148. Jensen EV, Jacobson HI, Walf AA, Frye CA. Estrogen action: A historic perspective on the implications of considering alternative approaches. Physiol Behav. 2010; 99: 151-62.

149. Prange-Kiel J, Rune GM. Direct and indirect effects of estrogen on rat hippocampus. Neuroscience. 2006; 138: 765-72.

150. Weiser MJ, Foradori CD, Handa RJ. Estrogen receptor beta in the brain: From form to function. Brain Res Rev. 2008; 57: 309-20.

151. Blaustein JD. Progestin receptors: neuronal integrators of hormonal and environmental stimulation. Ann N Y Acad Sci. 2003; 1007: 238-50.

152. Guerriero G, Ciarcia G. Progesterone receptor: some viewpoints on hypothalamic seasonal fluctuations in a lower vertebrate. Brain Res Rev. 2001; 37: $172-7$.

153. Mani SK. Signaling mechanisms in progesterone-neurotransmitter interactions. Neuroscience. 2006; 138: 773-81.

154. Adkins Regan EK, Mansukhani V, Thompson R, Yang S. Organizational action of sex hormones on sexual partner preference. Brain Res Bull. 1997; 44: 497502.

155. DonCarlos LL, Sarkey S, Lorenz B, Azcoitia I, Garcia-Ovejero D, Huppenbauer C, Garcia-Segura LM. Novel cellular phenotypes and subcellular sites for androgen action in the forebrain. Neuroscience. 2006; 138: 801-7.

156. Gahr M, Metzdorf R. Distribution and dynamics in the expression of androgen and estrogen receptors in vocal control systems of songbirds. Brain Res Bull. 1997; 44: $509-17$.

157. Guillamon A, Segovia S. Sex differences in the vomeronasal system. In: Hormones, Brain, and Behavior (G.C.Panzica and J.Balthazart eds). Brain Res Bull. 1997; 44: 377-82.

158. Walf AA. Oestrogen receptor beta is involved in the actions of oestrogens in the brain for affective behaviour, but not trophic effects in peripheral tissues. $J$ Neuroendocrinol. 2010; 22: 141-51.

159. Charlier TD. Importance of steroid receptor coactivators in the modulation of steroid action on brain and behavior. Psychoneuroendocrinology. 2009; 34 (Suppl. 1): $520-9$. 
160. Auger AP, Jessen HM. Corepressors, nuclear receptors, and epigenetic factors on DNA: A tail of repression. Psychoneuroendocrinology. 2009; 34 (Suppl.1): 3947.

161. Belcher SM. Rapid signaling mechanisms of estrogens in the developing cerebellum. Brain Res Rev. 2008; 57: 481-92.

162. Wandosell F, Varea O, Arevalo MA, Garcia-Segura LM. Oestradiol regulates beta-catenin-mediated transcription in neurones. J Neuroendocrinol. 2011.

163. Guennoun R, Meffre D, Labombarda F, Gonzalez SL, Deniselle MC, Stein DG, De Nicola AF, Schumacher M. The membrane-associated progesterone-binding protein 25-Dx: Expression, cellular localization and up-regulation after brain and spinal cord injuries. Brain Res Rev. 2008; 57: 493-505.

164. Mhyre AJ, Dorsa DM. Estrogen activates rapid signaling in the brain: role of estrogen receptor alpha and estrogen receptor beta in neurons and glia. Neuroscience. 2006; 138: 851-8.

165. Ramirez VD, Kipp JL, Joe I. Estradiol, in the CNS, targets several physiologically relevant membrane-associated proteins. Brain Res Rev. 2001; 37: $141-52$.

166. Akk G, Covey DF, Evers AS, Steinbach JH, Zorumski CF, Mennerick S. The influence of the membrane on neurosteroid actions at $\operatorname{GABA}(\mathrm{A})$ receptors. Psychoneuroendocrinology. 2009; 34 (Suppl.1): 59-66.

167. Covey DF, Evers AS, Mennerick S, Zorumski CF, Purdy RH. Recent developments in structure-activity relationships for steroid modulators of GABA(A) receptors. Brain Res Rev. 2001; 37: 91-7.

168. Follesa P, Concas A, Porcu P, Sanna E, Serra M, Mostallino MC, Purdy RH, Biggio G. Role of allopregnanolone in regulation of $\operatorname{GABA}(\mathrm{A})$ receptor plasticity during long-term exposure to and withdrawal from progesterone. Brain Res Rev. 2001; 37: 81-90.

169. Lambert JJ, Belelli D, Harney SC, Peters JA, Frenguelli BG. Modulation of native and recombinant $\mathrm{GABA}(\mathrm{A})$ receptors by endogenous and synthetic neuroactive steroids. Brain Res Rev. 2001; 37.

170. Lambert JJ, Cooper MA, Simmons RD, Weir CJ, Belelli D. Neurosteroids: Endogenous allosteric modulators of GABA(A) receptors. Psychoneuroendocrinology. 2009; 34 (Suppl.1): 48-58. 
171. Maguire J, Mody I. Steroid hormone fluctuations and GABA(A)R plasticity. Psychoneuroendocrinology. 2009; 34 (Suppl.1): 84-90.

172. McCarthy MM, Davis AM, Mong JA. Excitatory neurotransmission and sexual differentiation of the brain. Brain Res Bull. 1997; 44: 487-95.

173. Smith CC, Vedder LC, McMahon LL. Estradiol and the relationship between dendritic spines, NR2B containing NMDA receptors, and the magnitude of long-term potentiation at hippocampal CA3-CA1 synapses. Psychoneuroendocrinology. 2009; 34 (Suppl.1): 130-42.

174. Cyr M, Ghribi O, Thibault C, Morissette M, Landry M, Di Paolo T. Ovarian steroids and selective estrogen receptor modulators activity on rat brain NMDA and AMPA receptors. Brain Res Rev. 2001; 37: 153-61.

175. Hull EM, Du J, Lorrain DS, Matuszewich L. Testosterone, preoptic dopamine, and copulation in male rats. In: Hormones, Brain, and Behavior (G.C.Panzica and J.Balthazart eds). Brain Res Bull. 1997; 44: 327-33.

176. Etgen AM, Gonzalez-Flores O, Todd BJ. The role of insulin-like growth factor-I and growth factor-associated signal transduction pathways in estradiol and progesterone facilitation of female reproductive behaviors. Front Neuroendocrinol. 2006; 27: 363-75.

177. Herbison AE. Estrogen regulation of GABA transmission in rat preoptic area. Brain Res Bull. 1997; 44: 321-6.

178. Micevych PE, Eckersell CB, Brecha N, Holland KL. Estrogen modulation of opioid and cholecystokinin systems in the limbic-hypothalamic circuit. Brain Res Bull. 1997; 44: 335-43.

179. Maurice T, Urani A, Phan VL, Romieu P. The interaction between neuroactive steroids and the sigma(1) receptor function: behavioral consequences and therapeutic opportunities. Brain Res Rev. 2001; 37: 116-32.

180. Dewing P, Christensen A, Bondar G, Micevych P. Protein kinase C signaling in the hypothalamic arcuate nucleus regulates sexual receptivity in female rats. Endocrinology. 2008; 149: 5934-42.

181. Frye CA. Neurosteroids' effects and mechanisms for social, cognitive, emotional, and physical functions. Psychoneuroendocrinology. 2009; 34 (Suppl.1): 143-61.

182. Simpkins JW, Dykens JA. Mitochondrial mechanisms of estrogen neuroprotection. Brain Res Rev. 2008; 57: 421-30. 
183. Micevych PE, Mermelstein PG. Membrane estrogen receptors acting through metabotropic glutamate receptors: an emerging mechanism of estrogen action in brain. Mol Neurobiol. 2008; 38: 66-77.

184. Meitzen J, Mermelstein PG. Estrogen receptors stimulate brain region specific metabotropic glutamate receptors to rapidly initiate signal transduction pathways. $J$ Chem Neuroanat. 2011; 42: 236-41.

185. Rapp SR, Espeland MA, Shumaker SA, Henderson VW, Brunner RL, Manson JE, Gass ML, Stefanick ML, Lane DS, Hays J, Johnson KC, Coker LH, Dailey M, Bowen D. Effect of estrogen plus progestin on global cognitive function in postmenopausal women: the Women's Health Initiative Memory Study: a randomized controlled trial. JAMA. 2003; 289: 2663-72.

186. Rossouw JE, Anderson GL, Prentice RL, LaCroix AZ, Kooperberg C, Stefanick ML, Jackson RD, Beresford SA, Howard BV, Johnson KC, Kotchen JM, Ockene J. Risks and benefits of estrogen plus progestin in healthy postmenopausal women: principal results From the Women's Health Initiative randomized controlled trial. JAMA. 2002; 288: 321-33.

187. Maki PM. Hormone therapy and cognitive function: is there a critical period for benefit? Neuroscience. 2006; 138: 1027-30.

188. Brann D, Raz L, Wang R, Vadlamudi R, Zhang Q. Estrogen signaling and neuroprotection in cerebral ischemia. J Neuroendocrinol. 2011.

189. Azcoitia I, Arevalo MA, De Nicola AF, Garcia-Segura LM. Neuroprotective actions of estradiol revisited. Trends Endocrinol Metab. 2011.

190. Ciriza I, Carrero P, Frye CA, Garcia-Segura LM. Reduced metabolites mediate neuroprotective effects of progesterone in the adult rat hippocampus. The synthetic progestin medroxyprogesterone acetate (Provera) is not neuroprotective. $J$ Neurobiol. 2006; 66: 916-28.

191. De Nicola AF, Labombarda F, Deniselle MC, Gonzalez SL, Garay L, Meyer M, Gargiulo G, Guennoun R, Schumacher M. Progesterone neuroprotection in traumatic CNS injury and motoneuron degeneration. Front Neuroendocrinol. 2009; 30: $173-87$.

192. Sayeed I, Stein DG. Progesterone as a neuroprotective factor in traumatic and ischemic brain injury. Prog Brain Res. 2009; 175: 219-37.

193. Ibanez C, Shields SA, El-Etr M, Leonelli E, Magnaghi V, Li WW, Sim FJ, Baulieu EE, Melcangi RC, Schumacher M, Franklin RJ. Steroids and the reversal of 
age-associated changes in myelination and remyelination. Prog Neurobiol. 2003; 71: 49-56.

194. Schumacher M, Sitruk-Ware R, De Nicola AF. Progesterone and progestins: neuroprotection and myelin repair. Curr Opin Pharmacol. 2008; 8: 740-6.

195. Melcangi RC, Azcoitia I, Ballabio M, Cavarretta I, Gonzalez LC, Leonelli E, Magnaghi V, Veiga S, Garcia-Segura LM. Neuroactive steroids influence peripheral myelination: a promising opportunity for preventing or treating age-dependent dysfunctions of peripheral nerves. Prog Neurobiol. 2003; 71: 57-66.

196. Melcangi RC, Cavarretta IT, Ballabio M, Leonelli E, Schenone A, Azcoitia I, Miguel Garcia-Segura L, Magnaghi V. Peripheral nerves: a target for the action of neuroactive steroids. Brain Res Brain Res Rev. 2005; 48: 328-38.

197. Roglio I, Bianchi R, Gotti S, Scurati S, Giatti S, Pesaresi M, Caruso D, Panzica GC, Melcangi RC. Neuroprotective effects of dihydroprogesterone and progesterone in an experimental model of nerve crush injury. Neuroscience. 2008; 155: $673-85$.

198. Garay L, Deniselle MC, Lima A, Roig P, De Nicola AF. Effects of progesterone in the spinal cord of a mouse model of multiple sclerosis. J Steroid Biochem Mol Biol. 2007; 107: 228-37.

199. Garay L, Deniselle MC, Meyer M, Costa JJ, Lima A, Roig P, De nicola AF. Protective effects of progesterone administration on axonal pathology in mice with experimental autoimmune encephalomyelitis. Brain Res. 2009; 1283: 177-85.

200. Kipp M, Beyer C. Impact of sex steroids on neuroinflammatory processes and experimental multiple sclerosis. Front Neuroendocrinol. 2009; 30: 188-200.

201. Kipp M, Berger K, Clarner T, Dang J, Beyer C. Sex steroids control neuroinflammatory processes in the brain: relevance for acute ischemia and degenerative demyelination. J Neuroendocrinol. 2011.

202. Leonelli E, Bianchi R, Cavaletti G, Caruso D, Crippa D, Garcia-Segura LM, Lauria G, Magnaghi V, Roglio I, Melcangi RC. Progesterone and its derivatives are neuroprotective agents in experimental diabetic neuropathy: a multimodal analysis. Neuroscience. 2007; 144: 1293-304.

203. Stein DG. Progesterone in the treatment of acute traumatic brain injury: a clinical perspective and update. Neuroscience. 2011; 191: 101-6. 
204. Griffin LD, Gong W, Verot L, Mellon SH. Niemann-Pick type C disease involves disrupted neurosteroidogenesis and responds to allopregnanolone. Nat Med. 2004; 10: 704-11.

205. Fiore C, Inman DM, Hirose S, Noble LJ, Igarashi T, Compagnone NA. Treatment with the neurosteroid dehydroepiandrosterone promotes recovery of motor behavior after moderate contusive spinal cord injury in the mouse. J Neurosci Res. 2004; 75: 391-400.

206. Pesaresi M, Giatti S, Cavaletti G, Abbiati F, Calabrese D, Lombardi R, Bianchi R, Lauria G, Caruso D, Garcia-Segura LM, Melcangi RC. Sex-dimorphic effects of dehydroepiandrosterone in diabetic neuropathy. Neuroscience. 2011.

207. Schule C, Eser D, Baghai TC, Nothdurfter C, Kessler JS, Rupprecht R. Neuroactive steroids in affective disorders: target for novel antidepressant or anxiolytic drugs? Neuroscience. 2011; 191: 55-77.

208. Marx CE, Bradford DW, Hamer RM, Naylor JC, Allen TB, Lieberman JA, Strauss JL, Kilts JD. Pregnenolone as a novel therapeutic candidate in schizophrenia: emerging preclinical and clinical evidence. Neuroscience. 2011; 191: 78-90.

209. Ritsner MS. The clinical and therapeutic potentials of dehydroepiandrosterone and pregnenolone in schizophrenia. Neuroscience. 2011; 191: 91-100.

210. Arevalo MA, Diz-Chaves Y, Santos-Galindo M, Bellini MJ, Garcia-Segura LM. Selective Oestrogen Receptor Modulators Decrease the Inflammatory Response of Glial Cells. J Neuroendocrinol. 2011.

211. Pinna G, Rasmusson AM. Upregulation of neurosteroid biosynthesis as a pharmacological strategy to improve behavioral deficits in a putative mouse model of PTSD. J Neuroendocrinol. 2011.

212. Papadopoulos V, Lecanu L. Caprospinol: Discovery of a Steroid Drug Candidate to Treat Alzheimer's Disease Based on 22r-Hydroxycholesterol Structure and Properties. J Neuroendocrinol. 2011.

213. Girard C, Liu S, Adams D, Lacroix C, Sineus M, Boucher C, Papadopoulos V, Rupprecht R, Schumacher M, Groyer G. Axonal Regeneration and Neuroinflammation: Roles for the Translocator Protein $18 \mathrm{kDa}$ (TSPO). $J$ Neuroendocrinol. 2011.

214. Nothdurfter C, Rammes G, Baghai TC, Schule C, Schumacher M, Papadopoulos V, Rupprecht R. TSPO (18 kDa) as a target for novel anxiolytics with a favourable side-effect profile J Neuroendocrinol. 2011. 
215. Leonelli E, Yague JG, Ballabio M, Azcoitia I, Magnaghi V, Schumacher M, Garcia-Segura LM, Melcangi RC. Ro5-4864, a synthetic ligand of peripheral benzodiazepine receptor, reduces aging-associated myelin degeneration in the sciatic nerve of male rats. Mech Ageing Dev. 2005; 126: 1159-63.

216. Giatti S, Pesaresi M, Cavaletti G, Bianchi R, Carozzi V, Lombardi R, Maschi O, Lauria G, Garcia-Segura LM, Caruso D, Melcangi RC. Neuroprotective effects of a ligand of translocator protein-18 $\mathrm{kDa}$ (Ro5-4864) in experimental diabetic neuropathy. Neuroscience. 2009; 164: 520-9.

217. Veiga S, Azcoitia I, Garcia-Segura LM. Ro5-4864, a peripheral benzodiazepine receptor ligand, reduces reactive gliosis and protects hippocampal hilar neurons from kainic acid excitotoxicity. J Neurosci Res. 2005; 80: 129-37.

218. Cermenati G, Giatti S, Cavaletti G, Bianchi R, Maschi O, Pesaresi M, Abbiati F, Volonterio A, Saez E, Caruso D, Melcangi RC, Mitro N. Activation of the liver X receptor increases neuroactive steroid levels and protects from diabetes-induced peripheral neuropathy. J Neurosci. 2010; 30: 11896-901.

219. Caruso D, Scurati S, Maschi O, De Angelis L, Roglio I, Giatti S, GarciaSegura LM, Melcangi RC. Evaluation of neuroactive steroid levels by liquid chromatography-tandem mass spectrometry in central and peripheral nervous system: effect of diabetes. Neurochem Int. 2008; 52: 560-8.

220. Mensah-Nyagan AG, Saredi S, Schaeffer V, Kibaly C, Meyer L, Melcangi RC, Patte-Mensah C. Assessment of neuroactive steroid formation in diabetic rat spinal cord using high-performance liquid chromatography and continuous flow scintillation detection. Neurochem Int. 2008; 52: 554-9.

221. Pesaresi M, Maschi O, Giatti S, Garcia-Segura LM, Caruso D, Melcangi RC. Sex differences in neuroactive steroid levels in the nervous system of diabetic and non-diabetic rats. Horm Behav. 2010; 57: 46-55.

222. Roglio I, Giatti S, Pesaresi M, Bianchi R, Cavaletti G, Lauria G, GarciaSegura LM, Melcangi RC. Neuroactive steroids and peripheral neuropathy. Brain Res Rev. 2008; 57: 460-9.

223. Labombarda F, Pianos A, Liere P, Eychenne B, Gonzalez S, Cambourg A, De Nicola AF, Schumacher M, Guennoun R. Injury elicited increase in spinal cord neurosteroid content analyzed by gas chromatography mass spectrometry. Endocrinology. 2006; 147: 1847-59. 
224. Meffre D, Pianos A, Liere P, Eychenne B, Cambourg A, Schumacher M, Stein DG, Guennoun R. Steroid profiling in brain and plasma of male and pseudopregnant female rats after traumatic brain injury: analysis by gas chromatography/mass spectrometry. Endocrinology. 2007; 148: 2505-17.

225. Caruso D, D'Intino G, Giatti S, Maschi O, Pesaresi M, Calabrese D, GarciaSegura LM, Calza L, Melcangi RC. Sex-dimorphic changes in neuroactive steroid levels after chronic experimental autoimmune encephalomyelitis. J Neurochem. 2010; 114: 921-32.

226. Giatti S, D'Intino G, Maschi O, Pesaresi M, Garcia-Segura LM, Calza L, Caruso D, Melcangi RC. Acute experimental autoimmune encephalomyelitis induces sex dimorphic changes in neuroactive steroid levels. Neurochem Int. 2010; 56: 11827.

227. Biamonte F, Assenza G, Marino R, D'Amelio M, Panteri R, Caruso D, Scurati S, Yague JG, Garcia-Segura LM, Cesa R, Strata P, Melcangi RC, Keller F. Interactions between neuroactive steroids and reelin haploinsufficiency in Purkinje cell survival. Neurobiol Dis. 2009; 36: 103-15.

228. Melcangi RC, Caruso D, Levandis G, Abbiati F, Armentero MT, Blandini F. Modifications of Neuroactive Steroid Levels in an Experimental Model of Nigrostriatal Degeneration: Potential Relevance to the Pathophysiology of Parkinson's Disease. J Mol Neurosci. 2011.

229. Al Sweidi S, Sanchez MG, Bourque M, Morissette M, Dluzen D, Di Paolo T. Oestrogen receptors and signalling pathways: implications for neuroprotective effects of sex steroids in parkinson's disease. J Neuroendocrinol. 2011.

230. Ahboucha S, Pomier-Layrargues G, Mamer O, Butterworth RF. Increased levels of pregnenolone and its neuroactive metabolite allopregnanolone in autopsied brain tissue from cirrhotic patients who died in hepatic coma. Neurochem Int. 2006; 49: $372-8$.

231. Luchetti S, Bossers K, Van de Bilt S, Agrapart V, Morales RR, Frajese GV, Swaab DF. Neurosteroid biosynthetic pathways changes in prefrontal cortex in Alzheimer's disease. Neurobiol Aging. 2009.

232. Luchetti S, Bossers K, Frajese GV, Swaab DF. Neurosteroid biosynthetic pathway changes in substantia nigra and caudate nucleus in Parkinson's disease. Brain Pathol. 2010; 20: 945-51. 
Ten years of the Torino Steroids' Meeting

233. Luchetti S, Huitinga I, Swaab DF. Neurosteroid and GABA-A receptor alterations in Alzheimer's disease, Parkinson's disease and multiple sclerosis. Neuroscience. 2011; 191: 6-21.

234. Luchetti S, Bossers K, Van de Bilt S, Agrapart V, Morales RR, Frajese GV, Swaab DF. Neurosteroid biosynthetic pathways changes in prefrontal cortex in Alzheimer's disease. Neurobiol Aging. 2011; 32: 1964-76.

235. Weill-Engerer S, David JP, Sazdovitch V, Liere P, Eychenne B, Pianos A, Schumacher M, Delacourte A, Baulieu EE, Akwa Y. Neurosteroid quantification in human brain regions: comparison between Alzheimer's and nondemented patients. $J$ Clin Endocrinol Metab. 2002; 87: 5138-43.

236. Melcangi RC, Garcia-Segura LM. Sex-specific therapeutic strategies based on neuroactive steroids: In search for innovative tools for neuroprotection. Horm Behav. 2010; 57: 2-11.

237. Caruso D, Scurati S, Roglio I, Nobbio L, Schenone A, Melcangi RC. Neuroactive Steroid Levels in a transgenic rat model of CMT1A Neuropathy. $J$ Mol Neurosci. 2008; 34: 249-53.

238. di Michele F, Lekieffre D, Pasini A, Bernardi G, Benavides J, Romeo E. Increased neurosteroids synthesis after brain and spinal cord injury in rats. Neurosci Lett. 2000; 284: 65-8. 
Fig. 1 - Participants at the 6th International Meeting on Steroids and Nervous System, Torino, February 2011.

$1483 \times 880 \mathrm{~mm}(72 \times 72 \mathrm{DPI})$ 